Article

\title{
Numerical Study on the Effectiveness of Grouting Reinforcement on the Large Heaving Floor of the Deep Retained Goaf-Side Gateroad: A Case Study in China
}

\author{
Zhiyi Zhang ${ }^{1, *}$ and Hideki Shimada ${ }^{2}$ \\ 1 College of Geological and Mining Engineering, Xinjiang University, Ürümqi 830047, China \\ 2 Department of Earth Resources Engineering, Kyushu University, Fukuoka 819-0395, Japan; \\ shimada@mine.kyushu-u.ac.jp \\ * Correspondence: xjuzhiyi@163.com; Tel.: +86-0991-8592362
}

Received: 25 February 2018; Accepted: 9 April 2018; Published: 20 April 2018

\begin{abstract}
To study the effectiveness of grouting reinforcement on a large heaving floor of the retained goaf-side gateroad (RGSG) at a $900 \mathrm{~m}$ depth in the Zhuji coal mine, a numerical model involving strain softening constitutive material was built. First, the simulated deformations of the RGSG were compared with field data to verify the reliability of the numerical model. Then, the dynamic distribution of the stress in the RGSG floor was examined to reveal the mechanism of floor heave. Finally, grouting reinforcement was proposed to control the RGSG floor, and the corresponding effectiveness was verified by improving the rock mechanics of the floor strata based on the results of numerical uniaxial compressive tests. The results demonstrated that a fairly good match was achieved between the field and numerical data, and the proposed FLAC3D (Fast Lagrangian Analysis of Continua) numerical model was an effective approach to study the stability of the deep RGSG. A variation of the ratio between horizontal stress to vertical stress in the floor strata was the root cause of floor heave in the deep RGSG. Ideally, the floor heave could be reduced by $41 \%, 62 \%$, and $79 \%$ when the floor strata of $1 \mathrm{~m}$ depth were reinforced with grouting schemes I, II, and III, respectively.
\end{abstract}

Keywords: retained goaf-side gateroad (RGSG); floor heave; strain softening constitutive model; grouting reinforcement; deep underground coal mine

\section{Introduction of the Zhuji Underground Coal Mine}

\subsection{Geological and Engineering Conditions}

The Zhuji coal mine is a typical underground coal mine with a depth of $900 \mathrm{~m}$ in Huainan city, Anhui Province of China (Figure 1a). Its primarily mineable coal seam has an absolute gas emission quantity of $37.4 \mathrm{~m}^{3} / \mathrm{min}$ and a thickness of $1.2 \mathrm{~m}$. The immediate roof strata and floor strata of the mineable coal seam are both soft mudstone with thicknesses of $9.9 \mathrm{~m}$ and $13.1 \mathrm{~m}$, respectively, as shown in Figure 1b.

Typically, two gateroads and one coal face form a conventional U-shaped roadway layout (Figure 2a) where fresh air travels up the headgate and across the coal face; taking away mine gas, coal dust and heat; and then travels down the tailgate and is extracted. Part of the fresh air flows into the goaf area from the lower corner of the coal face as the coal face is not fully enclosed, and then flows out from the upper corner and takes some gas out of the goaf (blue line). The gas from the goaf cannot be taken away by the fresh air in the roadway due to the fact that an eddy always forms in the upper corner when air flows through the right angle there. As a consequence, gas overruns in the 
upper corner of the coal face [1,2]. Additionally, a large-sized coal pillar between two U-type longwall panels is needed to support the overburden and protect the gateroad space [3], as shown in Figure 2c, which causes serious coal resources waste and potential risk of rock burst $[4,5]$.

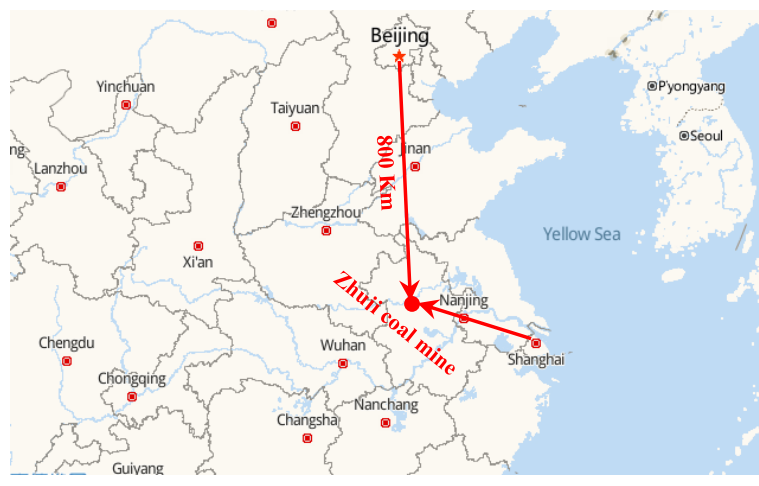

(a)

\begin{tabular}{|c|c|l|}
\hline Thickness/ m & Figure & Thickness/ m \\
\hline 9.9 & & Siltstone \\
\hline 11.3 & & Mudstone \\
\hline 3.1 & & Sandstone \\
\hline 9.9 & & Mudstone \\
\hline 1.2 & & Coal seam \\
\hline 13.1 & & Mudstone \\
\hline 6.9 & & Siltstone \\
\hline
\end{tabular}

(b)

Figure 1. Location of the target coalmine (a); and Geological columnar section (b).

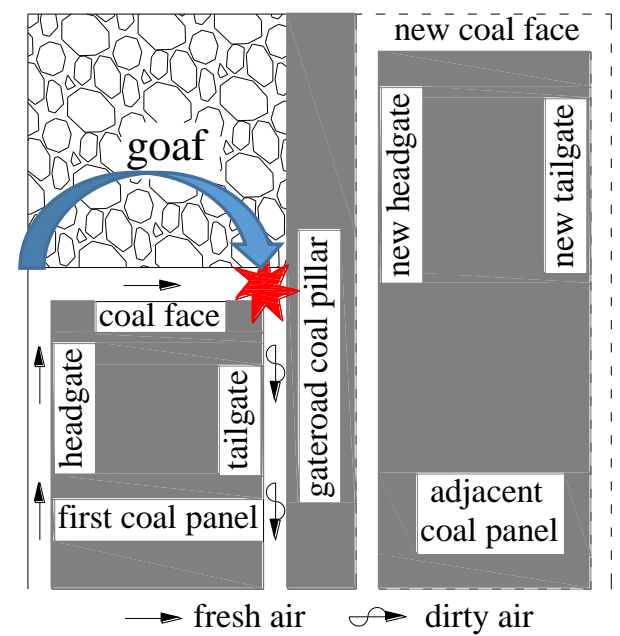

(a)

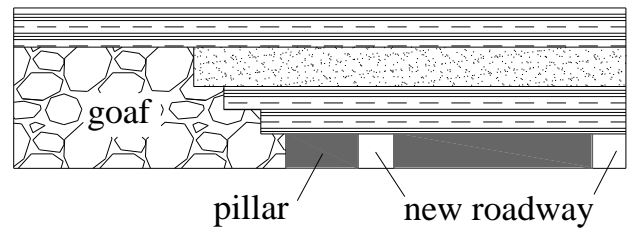

(c)

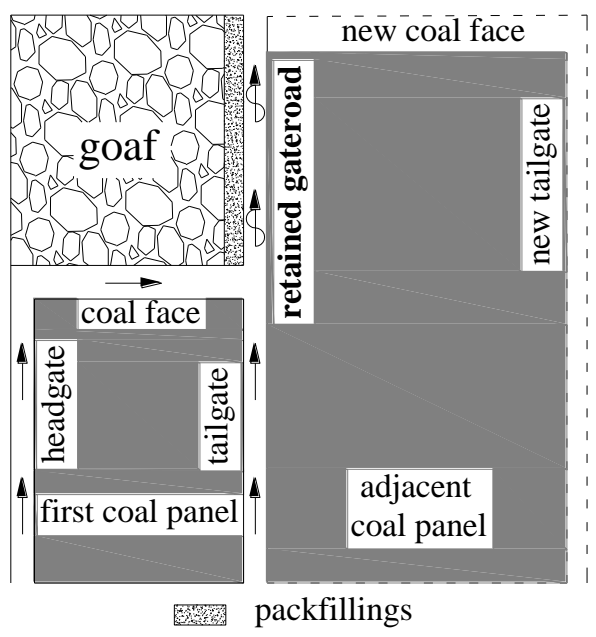

(b)

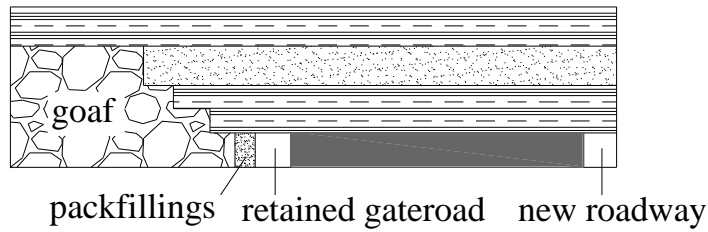

(d)

Figure 2. U type ventilation system (a); Y type ventilation system (b); Coal pillar reservation in U type settings (c); and Coal pillar reservation in $Y$ type settings $(\mathbf{d})$.

The Y-type longwall mining system based on a retained goaf-side gateroad (RGSG) was applied in this underground coal mine to reduce gas accumulation and coal resources waste. When one of the gateroads in the U-type longwall mining system is maintained as available after the coal face passes by, the ventilation system can be changed to a Y-shaped system (Figure 2b) where fresh air can flow in through two gateroads before the coal face and flow out from the RGSG behind the coal face. Consequently, the air flowing route is optimized, and gas overrun in the upper corner of the U-type longwall mining system is eliminated [6]. In the Y-type longwall mining system, the previous large coal pillar in the U-type settings is replaced by narrow artificial packfillings, as shown in Figure 2d, and the coal recovery rate can be considerably increased. Finally, this RGSG can be reused after the 
first longwall panel mining finishes, and the investment in excavating a new gateroad for the second longwall panel mining can be saved.

\subsection{Supporting Settings of the RGSG}

The roles of the RGSG determine that this roadway experiences several stress disturbances that are triggered by the roadway excavation and movement of the longwall panel. Staged roadway supporting technology has been used to keep the stability of the RGSG, as shown in Figure 3.

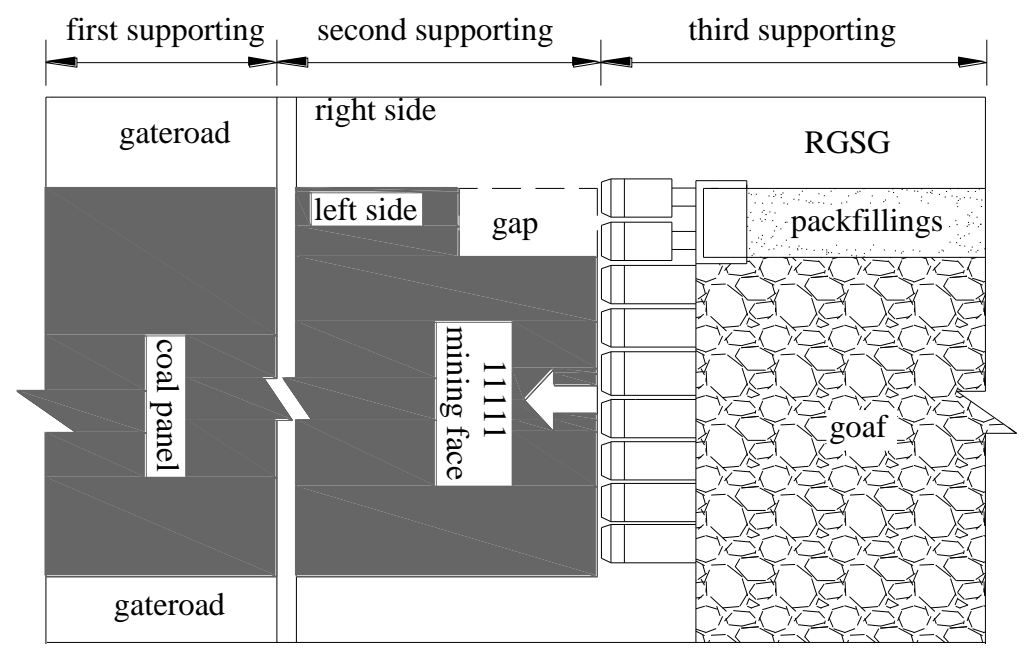

Figure 3. Distribution of the staged retained goaf-side gateroad (RGSG) supporting.

The principle of the staged supporting was to maintain the stability of the roadway roof and sidewalls during the RGSG service life, and the stability of the roadway floor was not considered as floor heave cannot directly endanger the life and safety of miners and equipment. In the first supporting stage, the supporting settings including the row and column for rock and cable bolts were designed based on a convention where the supporting intensity produced by the pretightening force of the rock and cable bolts should be larger than $0.25 \mathrm{MPa}$ in the roof and $0.12 \mathrm{MPa}$ in the sidewalls, respectively. This convention was concluded based on the type of surrounding rock (mudstone in the roof and floor; coal in the sidewalls) and the previous supporting experience in other coal mines with similar geological conditions. The pretightening force of the single rock and cable bolt was selected to be $60 \mathrm{kN}$ and $120 \mathrm{kN}$, respectively, according to the results of field tests. After calculation, the supporting settings in the first stage were five rock bolts in the sidewalls; seven rock bolts; and four cable bolts in the roof. The detailed parameters are presented in Figure 4a,c. During the second supporting stage, two cable bolts (red) were installed in the right sidewall and three cable bolts were installed in the roof to resist the disturbance of abutment stress induced by the coal face moving, and the detailed parameters are presented in Figure $4 \mathrm{~b}, \mathrm{~d}$. No cable bolt was installed in the left sidewall due to the fact that this part of the left sidewall was replaced by artificial packfillings. In the third supporting stage, an artificial packfillings was built using a mixture composed of $45 \%$ gravel, $23 \%$ cement, $23 \%$ sand, $8 \%$ fly ash, and $1 \%$ chemical additives by weight, and the water-cement ratio was 0.5. The uniaxial compressive strength of this solidified mixture was $15.6 \mathrm{MPa}, 25.6 \mathrm{MPa}, 30.5 \mathrm{MPa}$, and $37.0 \mathrm{MPa}$ after 1 day, 3 days, 7 days, and 28 days, respectively, according to the results of the laboratory tests. In addition, steel fabric was also preset in the packfillings frame to increase the bearing capacity of the packfillings. 


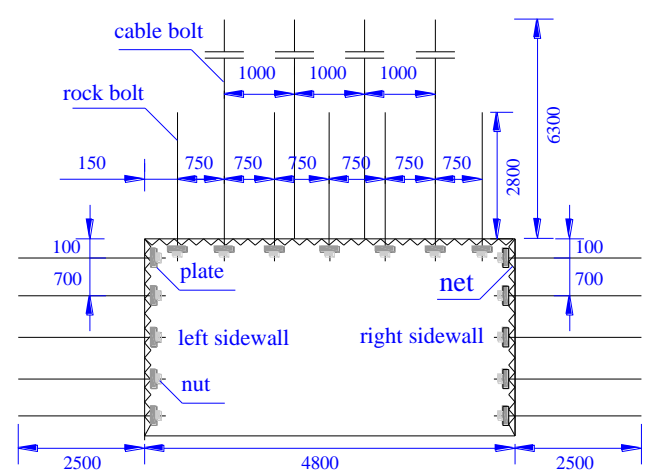

(a) (unit: $\mathrm{mm}$ )

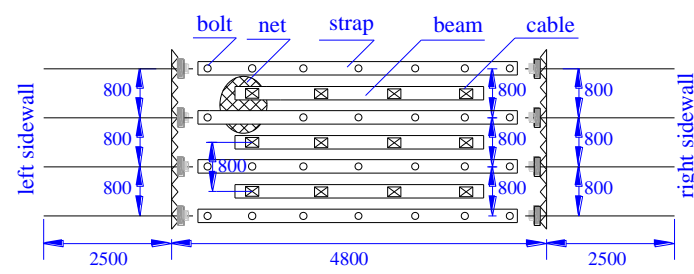

(c) (unit: $\mathrm{mm}$ )

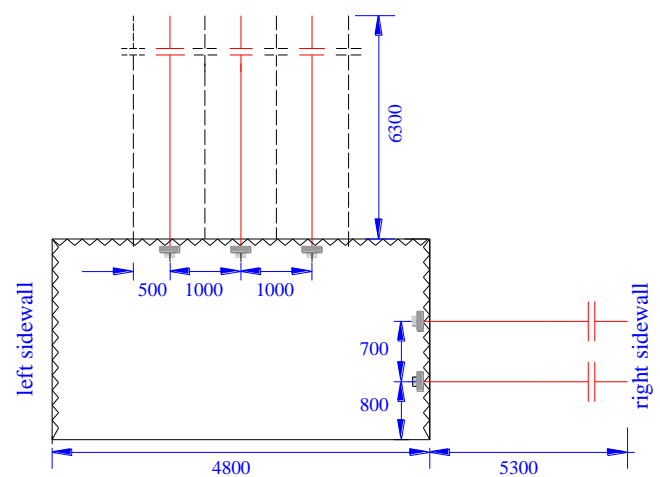

(b) (unit: $\mathrm{mm}$ )

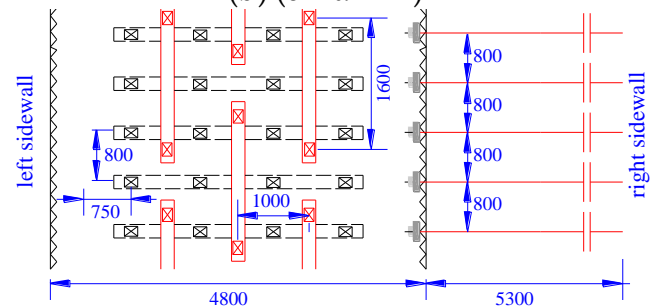

(d) (unit: $\mathrm{mm}$ )

Figure 4. Supporting parameters in the first supporting stage: section view (a) and top view (c); and supporting parameters in the second supporting stage: section view (b) and top view (d).

\subsection{Deformations of the RGSG}

The RGSG deformations were measured during the first longwall panel mining, and the result is shown in Figure 5. The RGSG performed large deformations after experiencing the stress disturbance produced by the first coal face moving. The height of the RGSG was reduced to $1.2 \mathrm{~m}$ from $3.0 \mathrm{~m}$, where floor heave made a contribution of $72 \%$. The residual section of roadway was so small that this roadway could not serve for the second longwall panel extraction. To provide enough space for the second longwall panel extraction, floor dinting was applied after the first longwall face stopped moving. This roadway repairing process increased the risk of roadway instability and mining costs.

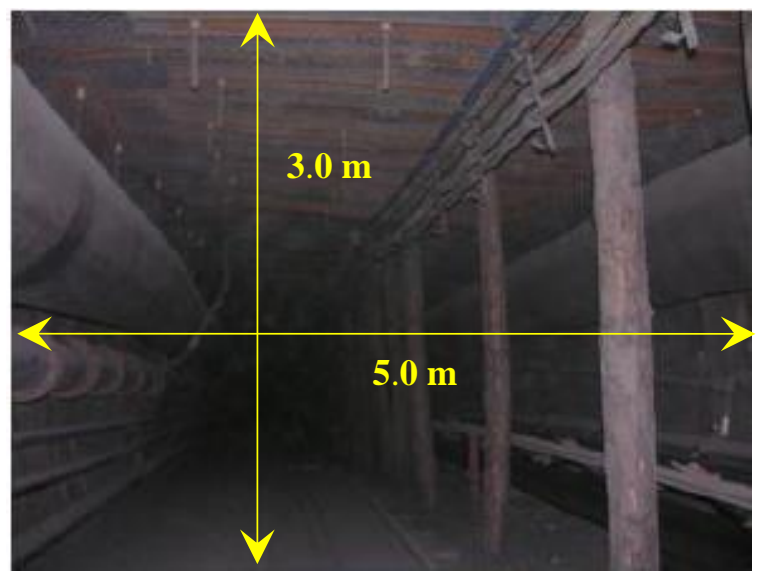

(a)

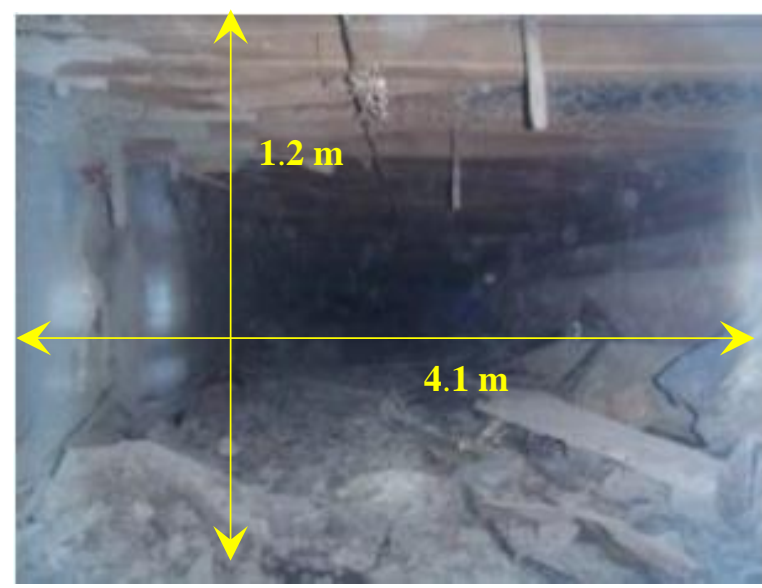

(b)

Figure 5. Profile of the RGSG before the first longwall panel mining (a) and profile of the RGSG when the first longwall face stopped moving (b).

In recent decades, many studies have been conducted on the stability control of the RGSG. Examples of such studies can be briefly generalized as follows: design principles, high-water material 
and mechanical calculating model for the packfillings were proposed in fully mechanized mining system in 2000, 2004, and 2008 [7-9]; the controlling methods of the stability of the RGSG packfillings, roof and sidewalls were researched in a backfilling mining system, inclined coal seam in 2010, 2011, 2013, and 2014 [10-13]; and the construction methods of the RGSG packfillings under hard roof strata, composed roof strata, and soft roof strata was studied in 2015, 2016, and 2017 [14-16]. The roof and sidewalls of the RGSG were maintained within acceptable limits according to the aforementioned advanced supporting theory and techniques.

As mining depth increases, however, a large floor heave of the RGSG is encountered which results from high in-situ stresses and soft rock mechanics associated with deep mining conditions. Several studies have been done to solve the challenge of serious floor heave, for example, Chen et al. clarified that reinforcing the solid coal sidewall and floor corner could limit a large floor heave of the RGSG in 2012 [17]; Tang et al. researched the floor heaving mechanism of the RGSG with swelling ground in 2012 and 2013 [18,19]; Sun et al. simulated the floor heaving phenomenon of a deep roadway in slight inclined strata using physical model in 2017 [20]; and Gong et al. studied the factors influencing the RGSG floor heave in backfilling mining and proposed their corresponding control methods including concrete pouring, stress relief slot, and deep grouting in 2017 [21]. Most of the conclusions were achieved on the assumption that the RGSG was disturbed by static stress induced by mining. In fact, the coal face beside the RGSG moves forward all the time during the whole service life of the roadway. The stress imposed on the RGSG is a dynamic disturbance. Furthermore, soft rock mechanics of the weak rock mass in a deep mining environment influences the behavior of the surrounding rock of a deep roadway greatly, which have rarely been considered in previous works. To create effective controlling technology to reduce the floor heave of a deep RGSG with soft surrounding rock, the mechanism and corresponding controlling method of the RGSG floor heave in the Zhuji coal mine was studied using a modified numerical model in the next section.

\section{Mechanism Study of the RGSG Floor Heave}

\subsection{Numerical Model}

In this section, a numerical model was built according to the geotechnical conditions of the Zhuji underground coal mine in China. The target simulation zone is illustrated in Figure 6a, and the simulation model is shown in Figure 6b. The model had the three-dimensional (3D) size of $270 \mathrm{~m}$ along the $\mathrm{x}$ direction, $400 \mathrm{~m}$ along the $\mathrm{y}$ direction, and $80 \mathrm{~m}$ along the $\mathrm{z}$ direction. Two longwall panels were considered, and half of the panel width was simulated due to symmetry. The height and width of the gateroad were $3.0 \mathrm{~m}$ and $5.0 \mathrm{~m}$, respectively. The height and width of the artificial packfillings were both $3 \mathrm{~m}$. The displacement boundaries of the model were set as a pinned boundary along the bottom and roller boundaries along the sides.

The stress boundaries of the model were set based on the results of field in-situ stress measurements: $19.0 \mathrm{MPa}$ in the $\mathrm{z}$ direction, $18.3 \mathrm{MPa}$ in the $\mathrm{y}$ direction, and $24.5 \mathrm{MPa}$ in the $\mathrm{x}$ direction. The coal seam, roof strata, and floor strata were set as strain softening constitutive material to model the softening behavior of the weak surroundings, whose strength decreased as the plastic shear strain increased, rather than remaining constant as that in the Mohr-Coulomb model [22]. The specific relationships between the decrements of a particular mechanical parameter and the shear strain increment was calculated using Equation (1) [23]. The other rock strata away from the coal seam were set as Mohr-Coulomb constitutive material. The final mechanics parameters used in this simulation are listed in Tables 1 and 2.

$$
\Delta k^{S}=\frac{1}{\sqrt{2}} \sqrt{\left(\Delta \epsilon_{1} P_{s}-\Delta \epsilon_{m}{ }^{P s}\right)^{2}+\left(\Delta \epsilon_{m}{ }^{P s}\right)^{2}+\left(\Delta \epsilon_{3}{ }^{P s}-\Delta \epsilon_{m}{ }^{P s}\right)^{2}}
$$

where $\Delta \epsilon_{1}{ }^{P s}$ and $\Delta \epsilon_{3}{ }^{P s}$ are the plastic shear increment in the directions of the maximum principal 
stress and minimum principal stress, respectively, and $\Delta \in_{m}{ }^{P s}$ is the volumetric plastic shear increment and can be calculated as Equation (2) [23].

$$
\Delta \in_{m}^{P s}=\frac{1}{3}\left(\Delta \epsilon_{1}^{P s}+\Delta \epsilon_{3}^{P s}\right)
$$
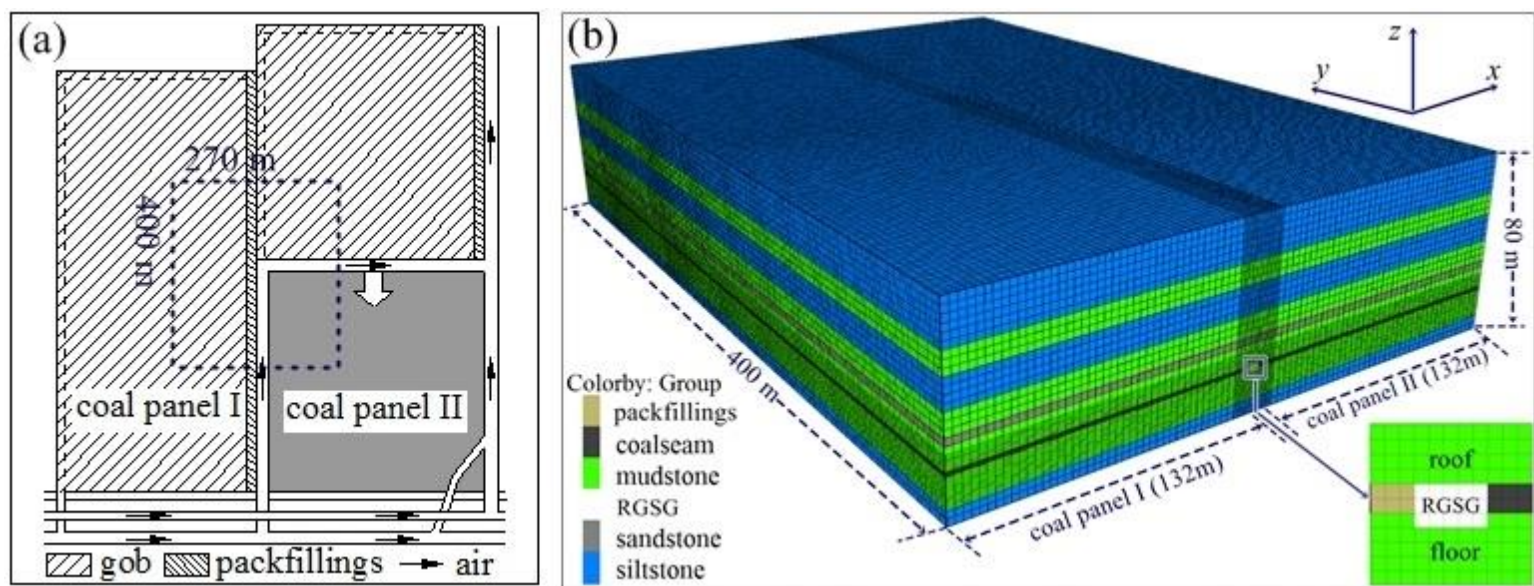

Figure 6. Plan view of the simulated area (a); and 3D dimensions of the model (b).

Table 1. Mechanics parameters of the rock mass used in simulation [24].

\begin{tabular}{ccccccc}
\hline No. & Strata & $\begin{array}{c}\text { Density } \\
\left(\mathbf{k g} / \mathbf{m}^{\mathbf{3}} \mathbf{)}\right.\end{array}$ & $\begin{array}{c}\text { Bulk Modulus } \\
\mathbf{( G P a )}\end{array}$ & $\begin{array}{c}\text { Shear Modulus } \\
(\mathbf{G P a})\end{array}$ & $\begin{array}{c}\text { Cohesion } \\
\mathbf{( M P a})\end{array}$ & $\begin{array}{c}\text { Friction Angle } \\
\left({ }^{\circ} \mathbf{)}\right.\end{array}$ \\
\hline 1 & Siltstone & 2700 & 2.68 & 1.84 & 2.0 & 32 \\
2 & Mudstone & 2300 & 3.03 & 1.56 & 1.2 & 27 \\
3 & Coal & 1400 & 1.19 & 0.37 & 0.8 & 23 \\
4 & Sandstone & 2600 & 5.56 & 4.17 & 2.0 & 35 \\
5 & Packfillings & 2500 & 5.00 & 4.20 & 3.0 & 35 \\
\hline
\end{tabular}

Table 2. Mechanical properties of coal and mudstone with different plastic shear strain.

\begin{tabular}{ccccccc}
\hline Mechanical Properties & & Coal (Coal Seam) & \multicolumn{2}{c}{ Mudstone (Immediate Roof and Floor) } \\
\hline Plastic shear strain & 0 & 0.1 & 0.2 & 0 & 0.1 & 0.2 \\
Cohesion $/(\mathrm{MPa})$ & 0.8 & 0 & 0 & 1.2 & 0 & 0 \\
Friction angle $/\left(^{\circ}\right)$ & 23 & 18 & 18 & 27 & 22 & 22 \\
\hline
\end{tabular}

The simulation sequence was as follows: (i) generated the initial stress; (ii) excavated the gateroad and installed the first roadway support; (iii) retreated coal panel I, removed the support in the left coal sidewall, and then built the artificial packfillings and installed the second roadway support; and (iv) retreated coal panel II. To model the limited support ability of the caved immediate roof strata, both the immediate roof and coal seam were excavated during the coal face retreating process, then, the excavation was filled using soft elastic material. The shear modulus and ultimate elastic bulk of this material were $0.268 \mathrm{GPa}$ and $0.156 \mathrm{GPa}$, respectively.

\subsection{Simulation Results}

During roadway and coal panel excavation, deformations of the surrounding rock of the RGSG were tracked and the simulated results were compared with the rear data collected in the field. Figure $7 \mathrm{a}$ represents the deformations of the roof and floor, and Figure $7 \mathrm{~b}$ shows the deformations of the coal sidewall and packfillings. The $\mathrm{x}$ coordinate is the relative distance to the coal face: the positive 
value represents the distance before the coal face and the negative value represents the distance back to the coal face.

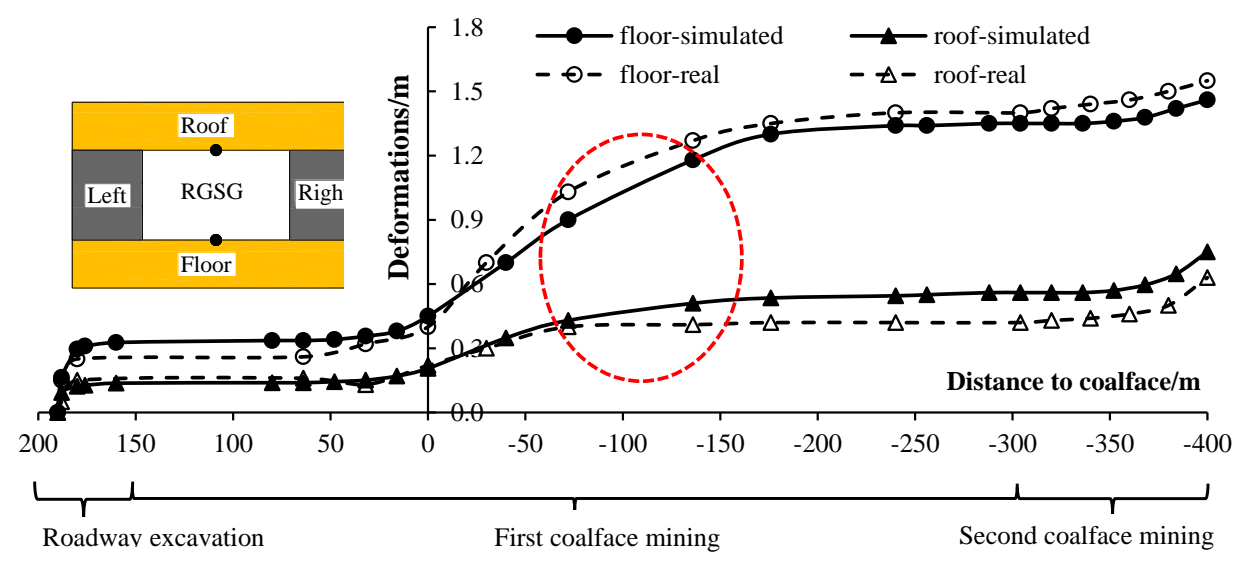

(a)

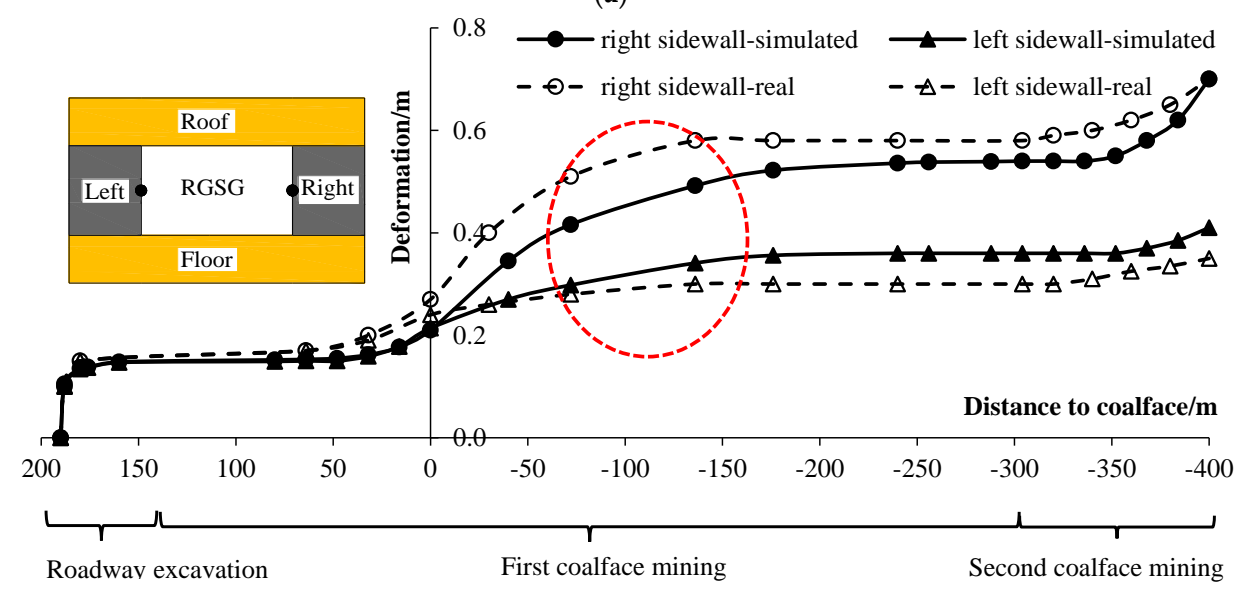

(b)

Figure 7. Deformation curves of the RGSG surrounding rock during mining process: Deformation of roof and floor (a); and Deformation of sidewalls $(\mathbf{b})$.

It can be observed from Figure 7a,b that the simulated deformations of the RGSG agreed well with the real deformations, and both performed a corresponding increment during different mining processes. In the influencing stage of roadway excavation, the deformations of the roof, floor, left sidewall, and right sidewall increased quickly to approximately $150 \mathrm{~mm}, 310 \mathrm{~mm}, 150 \mathrm{~mm}$, and $150 \mathrm{~mm}$, respectively. Then, the RGSG was disturbed by the extraction of coal panel I, and the deformations of the roof, floor, left sidewall, and right sidewall rose gradually up to approximately $570 \mathrm{~mm}, 1400 \mathrm{~mm}, 360 \mathrm{~mm}$, and $540 \mathrm{~mm}$, respectively, at the end of this stage. Finally, the RGSG was affected by coal panel II mining, and the deformations of the roof, floor, left sidewall, and right sidewall continually grew up to approximately $750 \mathrm{~mm}, 1460 \mathrm{~mm}, 410 \mathrm{~mm}$, and $700 \mathrm{~mm}$, respectively.

\subsection{Simulation Results Discussion}

Several conclusions can be drawn according to the above analyses:

(1) The strain softening constitutive material was more suitable for the simulation of large deformations of the deep RGSG surroundings. All the parameters including model size, rock mass mechanics and roadway support settings were verified to be effective, which provided a credible basis for the following analyses of floor heaving mechanism.

(2) The simulated deformations behind the coal face were slightly smaller than the real deformations, as the red circles illustrated, which indicated that backfilling the excavation with soft elastic 
material weakened the influence of the coal panel retreating on the RGSG to some extent when compared with the real scenario. This was possibly because caving of the immediate roof strata was a progressive process in the field, rather than backfilling the goaf space immediately after the coal was extracted. Thus, the caved rock in a real scenario could not provide effective support to the overlying strata in as timely a manner as in the simulation.

(3) The roof and sidewalls were controlled effectively by the present supporting structures. The deformations of the floor, however, were too large to serve again for the adjacent coal panel mining, and it had to be maintained (floor dinting), which increased the risk of mining accidents and mining costs. Profiles of the RGSG before coal panel II extraction are shown in Figure 8.

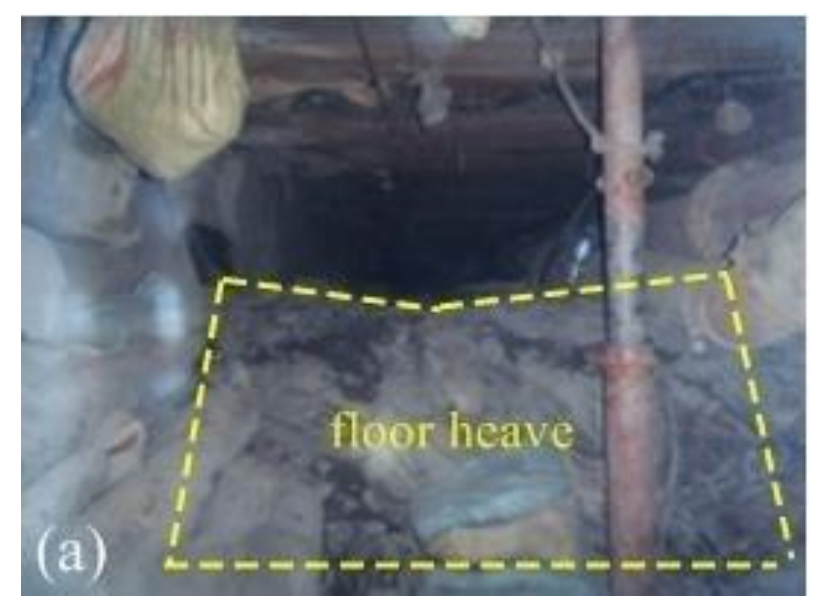

(a)

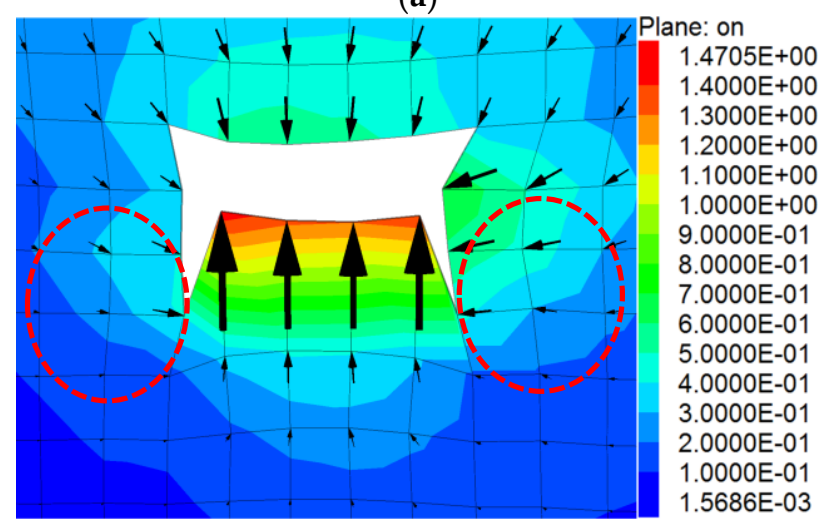

(b) (unit: m)

Figure 8. Comparison of real RGSG profile (a) and simulated RGSG profile (b).

\section{Mechanism of Floor Heave}

As shown in Figure 8b, the moving directions of the rock masses adjacent to the roadway floor strata were almost horizontal (red circles). This implied that floor heave was mainly attributed to the horizontal compression of the neighboring rock mass. Considering this fact, a mechanical model was built, as illustrated in Figure 9a. The vertical stress and horizontal stress in the floor strata were monitored during coal panel I retreating based on the FLAC3D model in the above section, and the results are presented in Figure 9b. As shown in Figure 9b, the vertical stress decreased quickly from the largest value of $3000 \mathrm{~Pa}$ at a distance of $50 \mathrm{~m}$ ahead of the coal face to the minimum value of $500 \mathrm{~Pa}$ at a distance of $40 \mathrm{~m}$ back to the coal face, then increased gradually to $1500 \mathrm{~Pa}$ until $240 \mathrm{~m}$ back to the coal face. The horizontal stress experienced a more complicated variation when compared with the vertical stress. At the beginning of the influencing stage of coal panel I, the horizontal stress rose from 
$0.8 \mathrm{MPa}$ up to a peak value of more than 1.0 MPa when the coal face passed by, then reduced sharply to approximately $0.65 \mathrm{MPa}$ when the distance behind the coal face was $40 \mathrm{~m}$. Furthermore, the horizontal stress rose again to another peak value of $0.8 \mathrm{MPa}$ when the distance back the coal face increased to $80 \mathrm{~m}$, and then decreased again to approximately $0.63 \mathrm{MPa}$ gradually until $240 \mathrm{~m}$ behind the coal face. The most obvious characteristic of the horizontal stress curve was the two crests before and behind the coal face. The crest before the coal face (peak 1) was the result of the horizontal stress redistribution triggered by the coal face moving, which was similar to the abutment pressure concentration in the roadway sidewall [24]. Another crest behind the coal face (peak 2) was the result of the packfillings construction and goaf backfilling.

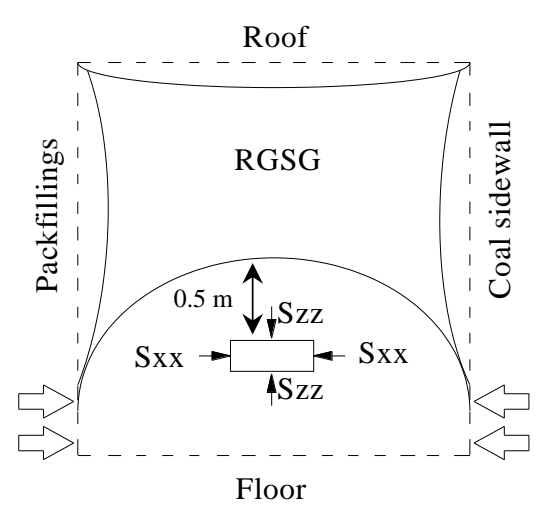

(a)

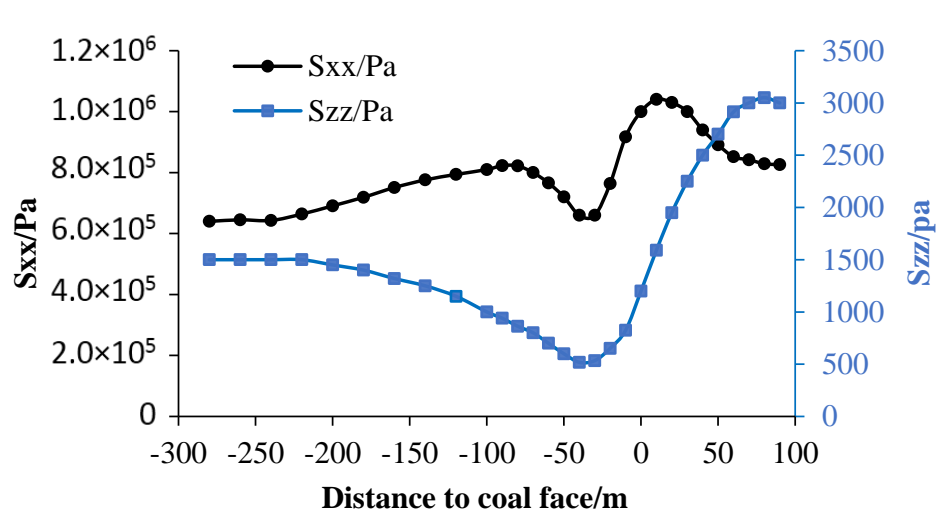

(b)

Figure 9. Mechanical model of floor heave (a) and variation of the stress in floor (b).

During the coal panel I retreating, the deformations at different depths of floor strata were also measured, and the results are presented in Figure 10, which shows that the floor heave began to increase approximately $50 \mathrm{~m}$ before the coal face and achieved the largest increasing speed at a distance of $40 \mathrm{~m}$ behind the coal face. Finally, the floor heave at the surface of the floor strata achieved the largest value of approximately $1300 \mathrm{~mm}$, approximately $240 \mathrm{~m}$ back to the coal face. Figure 10 also shows that the heave within a range of $1 \mathrm{~m}$ in the floor strata made the primary contribution, thereby accounting for $84 \%$ of the entire floor heave increment.

The most significant characteristic of the in-situ stress in the Zhuji coal mine was that the horizontal stress (Sxx) was much larger than the vertical stress (Szz). After the roadway excavation, the vertical stress in the floor strata acted as a confining stress, thus limiting floor heave. The horizontal stress, however, acted as compressive stress, thereby accelerating floor heave. Consequently, the final floor heave was a result of the interaction between these two stresses. The ratio of horizontal stress to vertical stress was calculated according the data in Figure $9 \mathrm{~b}$ and is shown by the blue curve in Figure 11. We found that this ratio increased quickly from a distance of $50 \mathrm{~m}$ ahead of the coal face and reached the peak point at a distance of $40 \mathrm{~m}$ back to the coal face, then decreased gradually as the distance behind the coal face continually increased and was finally kept almost unchangeable until $240 \mathrm{~m}$ back to the coal face. The variation of the increasing speed $(\mathrm{mm} / \mathrm{d})$ of the floor heave was also calculated according to the data in Figure 10, with the assumption that the coal face moved forward $5 \mathrm{~m}$ per day, and the results are illustrated by the black curves in Figure 11. It can be seen that the floor heaving speed well matched the variation tendency of the ratio between the horizontal stress to the vertical stress, which indicated that the root reason of floor heave at a certain position inside the floor strata was the variation of the ratio between horizontal stress to vertical stress. In addition, this stress ratio decreased relatively slowly when compared with the increase before the coal face. This is the reason why the floor heaving speed was kept at a higher level within a long period behind the coal face. Last but not least, the influencing of this stress ratio on the floor heave could be divided into a further three stages according to the value of the floor heaving speed: (1) slight influencing stage 
from $50 \mathrm{~m}$ to $16 \mathrm{~m}$ before the coal face; (2) intense influencing stage from $16 \mathrm{~m}$ before the coal face to $176 \mathrm{~m}$ behind the coal face; and (3) slight influencing stage from $176 \mathrm{~m}$ to $240 \mathrm{~m}$ behind the coal face. Accordingly, there was a critical level for this stress ratio and the critical ratio was approximately 550. The influencing stage division could provide suggestions for the opportunity of floor heaving control.

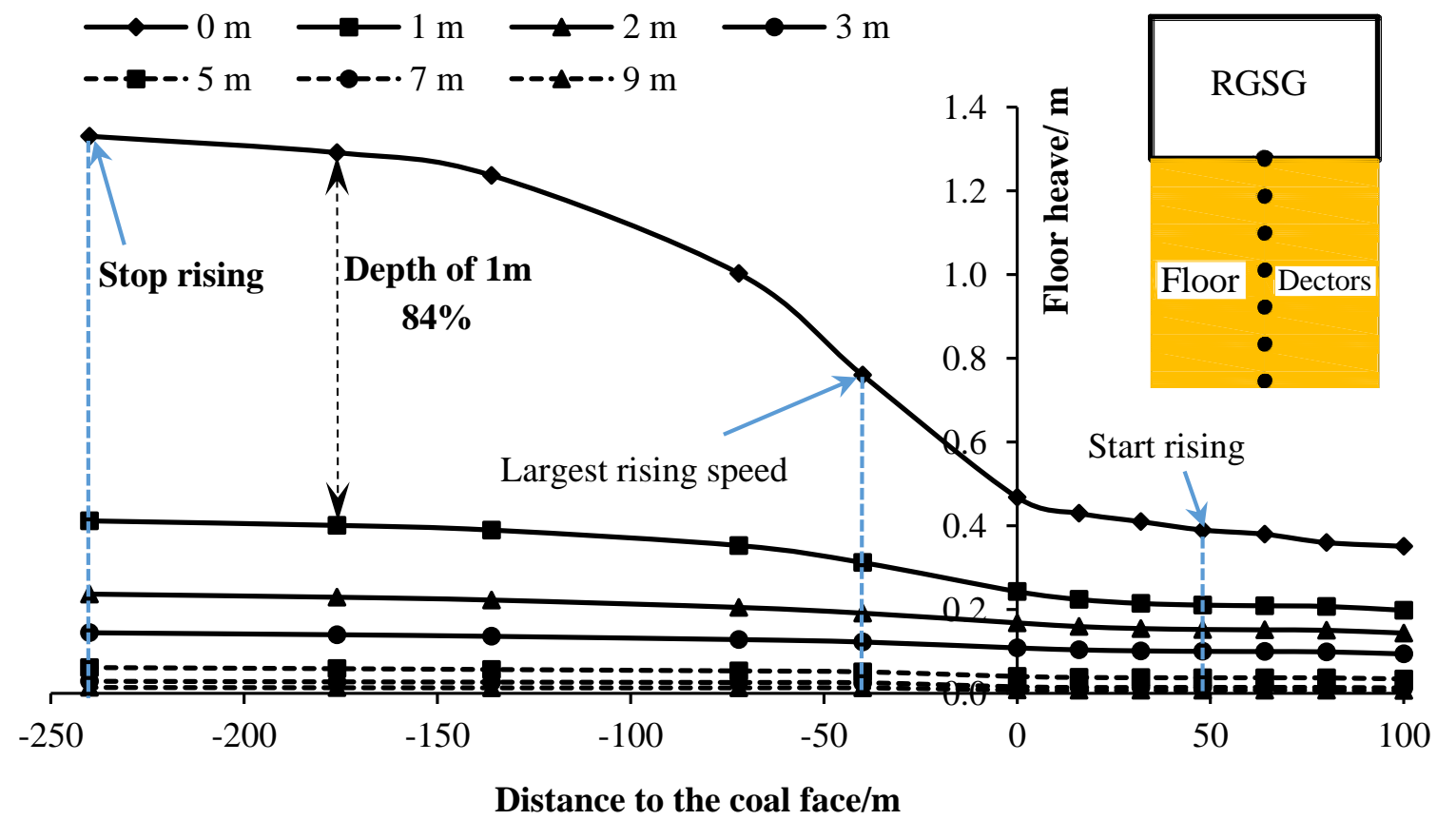

Figure 10. Heaves at different depth of the floor strata.

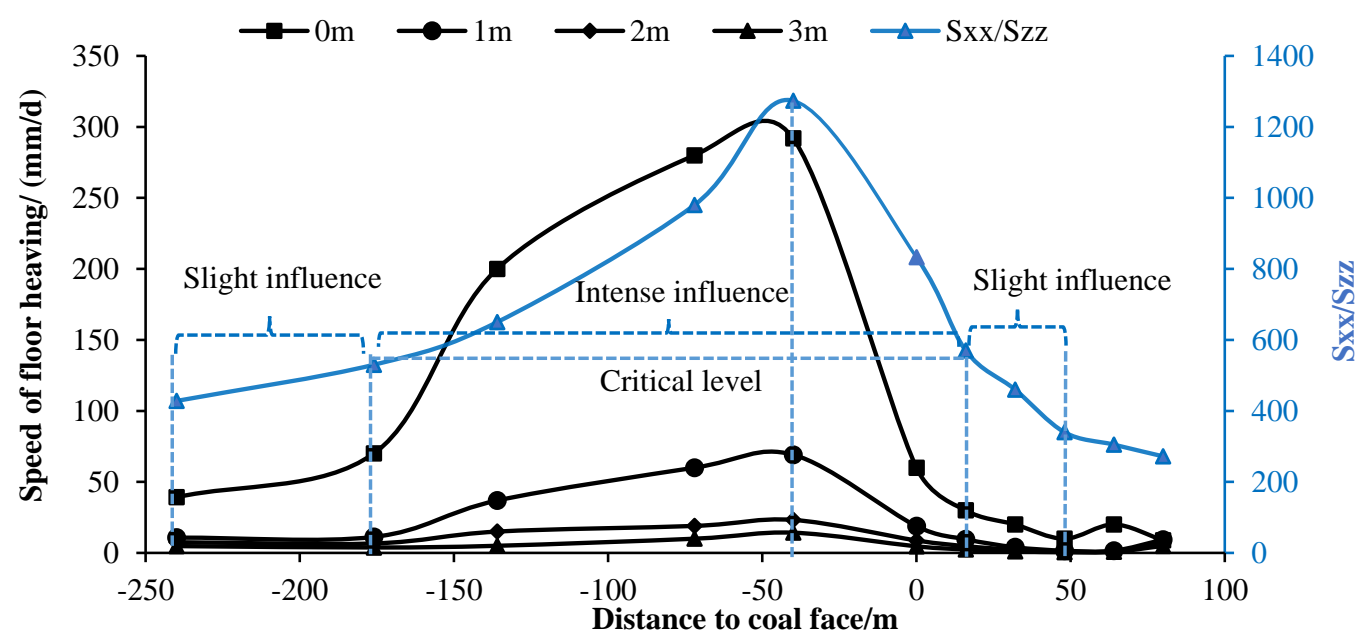

Figure 11. Heaving speed and stress ratio at different depth of the floor strata.

\section{Grouting Reinforcement of Floor Heave}

Over the last few decades, grouting technology has been widely applied in various geotechnical engineering for the purpose of strengthening or making them impermeable [25-27]. Poor rock conditions and severe stress disturbances were the main causes of the large floor heave of the RGSG in a deep underground coal mine. Regarding the former issue, grouting reinforcement provides incomparable advantages by fundamentally improving the mechanical parameters of the weak surrounding rock [28-30]. 


\subsection{Uniaxial Compressive Tests of Grouted Rock}

Due to high stress and low strength in a deep mining environment, the shallow part of the roadway surrounding rock yields and breaks in a short time after excavation, and then makes contributions to roadway section shrinkage, and even instability. Therefore, for a long time during a roadway's service life, this type of surrounding rock reacts to the external load with its residual strength. Additionally, grouting reinforcement is conducted after roadway excavation in the field; only the residual strength is anticipated to be improved when compared with that before grouting reinforcement. From this viewpoint, the four grouting schemes were where only the residual cohesion and friction angle were increased, as shown in Table 3.

Table 3. Residual cohesion and friction angle of floor strata after grouting.

\begin{tabular}{|c|c|c|c|c|}
\hline Grouting Schemes & Plastic Shear Strain & 0 & 0.1 & 0.2 \\
\hline \multirow{2}{*}{ Without grouting } & Cohesion (MPa) & 1.2 & 0 & 0 \\
\hline & Friction angle $\left(^{\circ}\right)$ & 27 & 22 & 22 \\
\hline \multirow{2}{*}{ Grouting I } & Cohesion $(\mathrm{MPa})$ & 1.2 & 0.1 & 0.1 \\
\hline & Friction angle $\left(^{\circ}\right)$ & 27 & 23 & 23 \\
\hline \multirow{2}{*}{ Grouting II } & Cohesion (MPa) & 1.2 & 0.35 & 0.35 \\
\hline & Friction angle $\left(^{\circ}\right)$ & 27 & 24 & 24 \\
\hline \multirow{2}{*}{ Grouting III } & Cohesion $(\mathrm{MPa})$ & 1.2 & 0.65 & 0.65 \\
\hline & Friction angle $\left({ }^{\circ}\right)$ & 27 & 25 & 25 \\
\hline \multirow{2}{*}{ Grouting IV } & Cohesion (MPa) & 1.2 & 0.9 & 0.9 \\
\hline & Friction angle $\left(^{\circ}\right)$ & 27 & 26 & 26 \\
\hline
\end{tabular}

As mentioned in Section 2.1, mudstone in the floor was set as a strain softening constitutive material to model the soft rock mechanics of the weak surrounding rock. To prepare for the next effectiveness evaluation of the grouting technology on the RGSG floor reinforcement, the exact relationship between the uniaxial compressive strength (UCS) and the mechanical parameters of the mudstone were studied using numerical uniaxial compressive tests. In the simulation, a representative cylinder-shaped rock sample with a diameter of $2 \mathrm{~m}$ and height of $4 \mathrm{~m}$ was used, the cohesion and friction angle of the rock sample were changed to model the improvements of different grouting schemes, and the residual strength of the rock sample was selected as a reference indicator to distinguish different grouting schemes. The simulated stress-strain curves of these grouting schemes are shown in Figure 12.

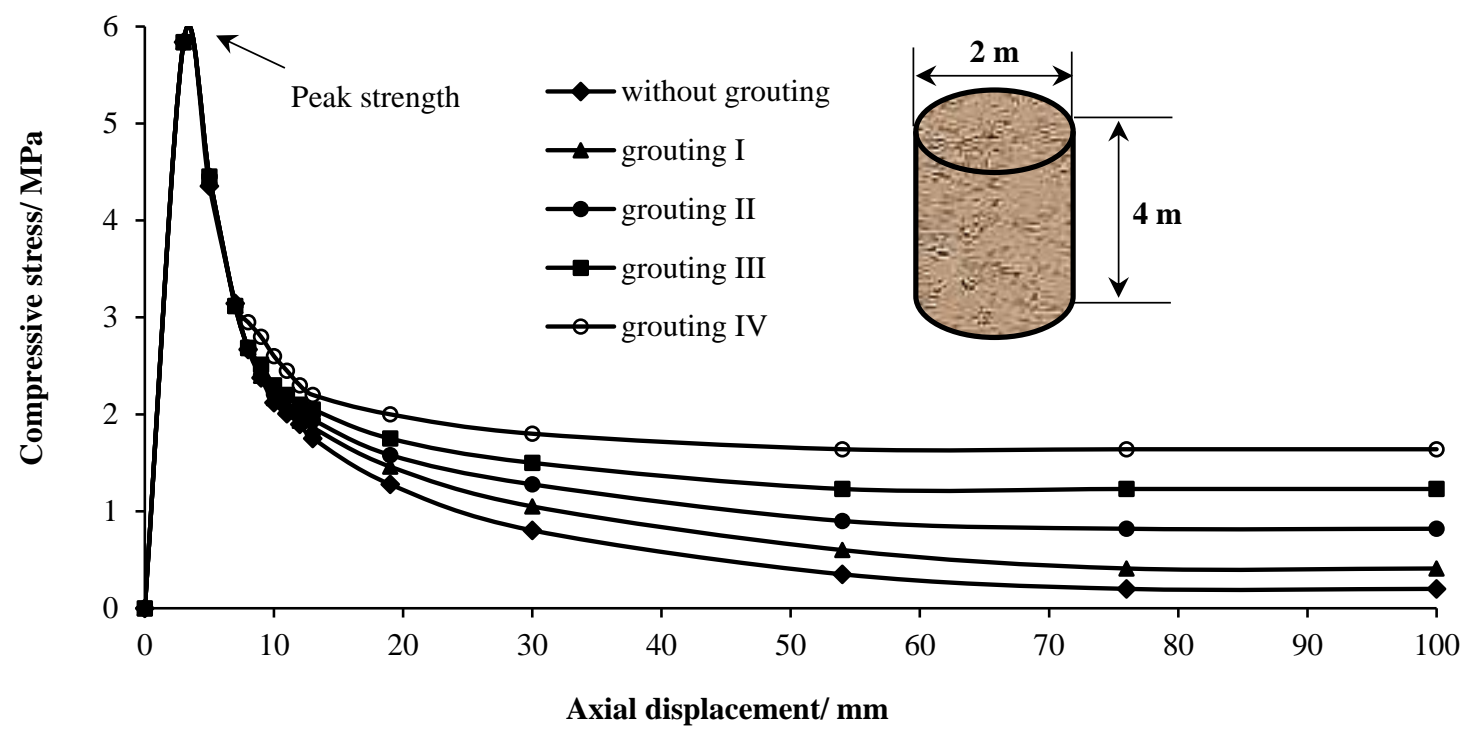

Figure 12. Stress-strain curves of different grouting schemes. 
We observed that the strength of the mudstone decreased gradually after yielding and finally maintained a certain value with a large displacement rather than dropping significantly to zero once the yield occurred. This behavior characteristic had a crucial role in the stability maintenance of the RGSG in response to the special mining conditions of the deep environment. Specifically, (1) without grouting, the residual strength was $0.41 \mathrm{MPa}$, which is equivalent to $6.8 \%$ of the peak strength; (2) with grouting $\mathrm{I}$, the residual strength was $0.82 \mathrm{MPa}$, which accounted for $13.7 \%$ of the peak strength; (3) with grouting II, the residual strength was $1.23 \mathrm{MPa}$, which equaled $20.5 \%$ of the peak strength; (4) with grouting III, the residual strength was $1.64 \mathrm{MPa}$, which accounted for $27.3 \%$ of the peak strength; and (5) with grouting IV, the residual strength was $2.05 \mathrm{MPa}$, which accounted for $34.2 \%$ of the peak strength.

\subsection{Effectiveness of Grouting Reinforcement on RGSG Floor Heave}

As analyzed in Section 3, the deformations within a $1 \mathrm{~m}$ depth of the floor strata were the main contributions to the entire floor heave. Therefore, only the rock mechanical parameters within a $1 \mathrm{~m}$ depth of the floor strata were improved according to the results of Section 4.1, and the other settings were the same as those of the model described in Section 2.1. During different mining operations, plastic zones-where most deformations occur under different grouting conditions-were also measured in the floor strata, and the final results are shown in Figure 13. Without grouting reinforcement, we observed that the plastic zone in floor strata was at most $2 \mathrm{~m}$ high and $5 \mathrm{~m}$ wide, and that this region of the floor strata was destroyed mainly due to tension. After grouting, the plastic zone was effectively reduced, and the rock failure mechanism partly became shear failure. Therefore, it was beneficial to the stability maintenance of the floor strata as the shear strength of the rock mass was typically larger than the tensile strength. Consequently, the floor heave on the surface of the floor strata, as illustrated in Figure 14, was significantly reduced. In particular, the floor heaves were decreased effectively by $41 \%, 62 \%$, and $79 \%$ when the floor strata were reinforced with grouting schemes I, II, and III, respectively. As the residual strength continually increased, however, floor heave was not obviously reduced any further.

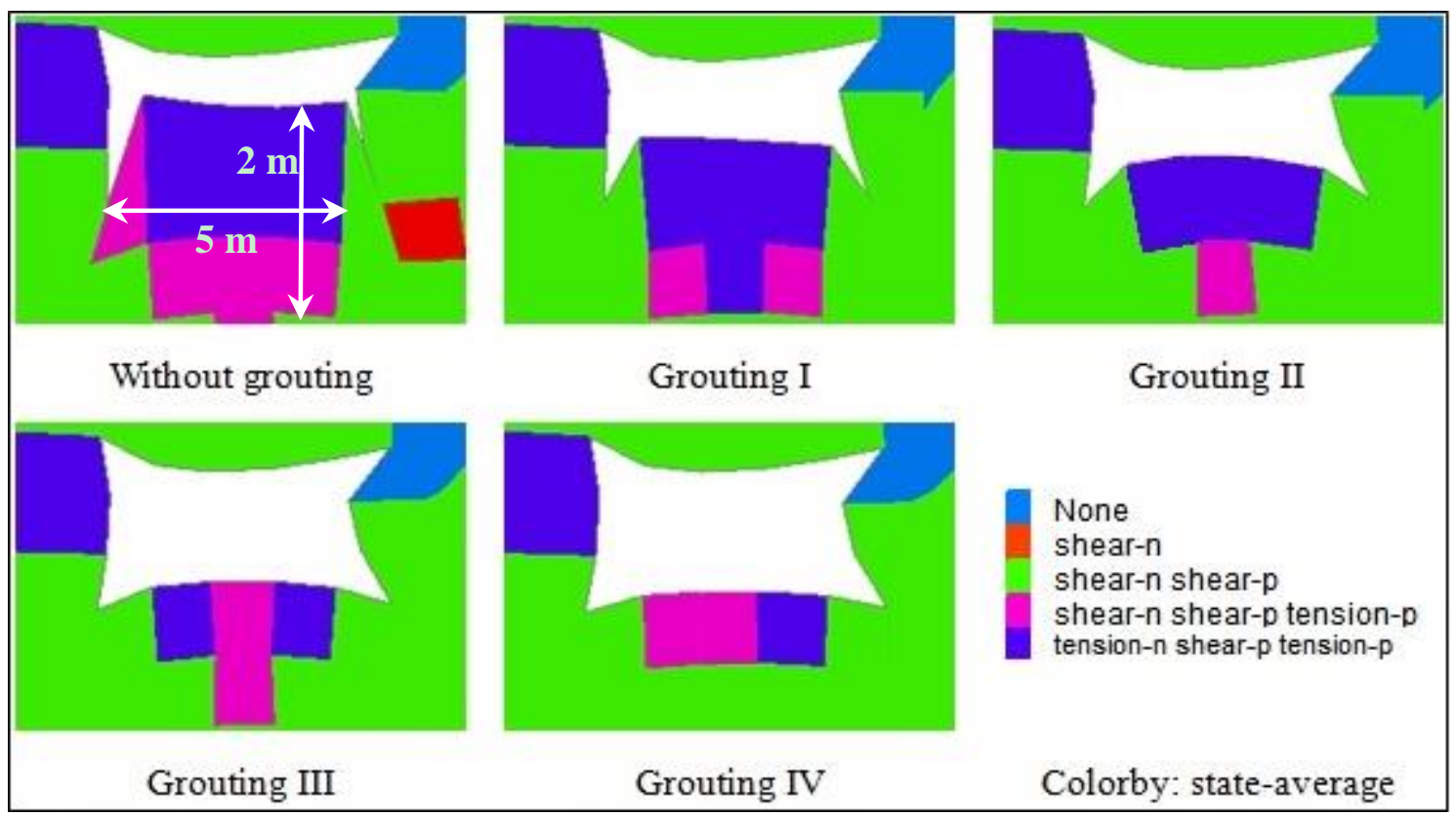

Figure 13. Plastic zone distribution in floor strata reinforced by different grouting schemes. 


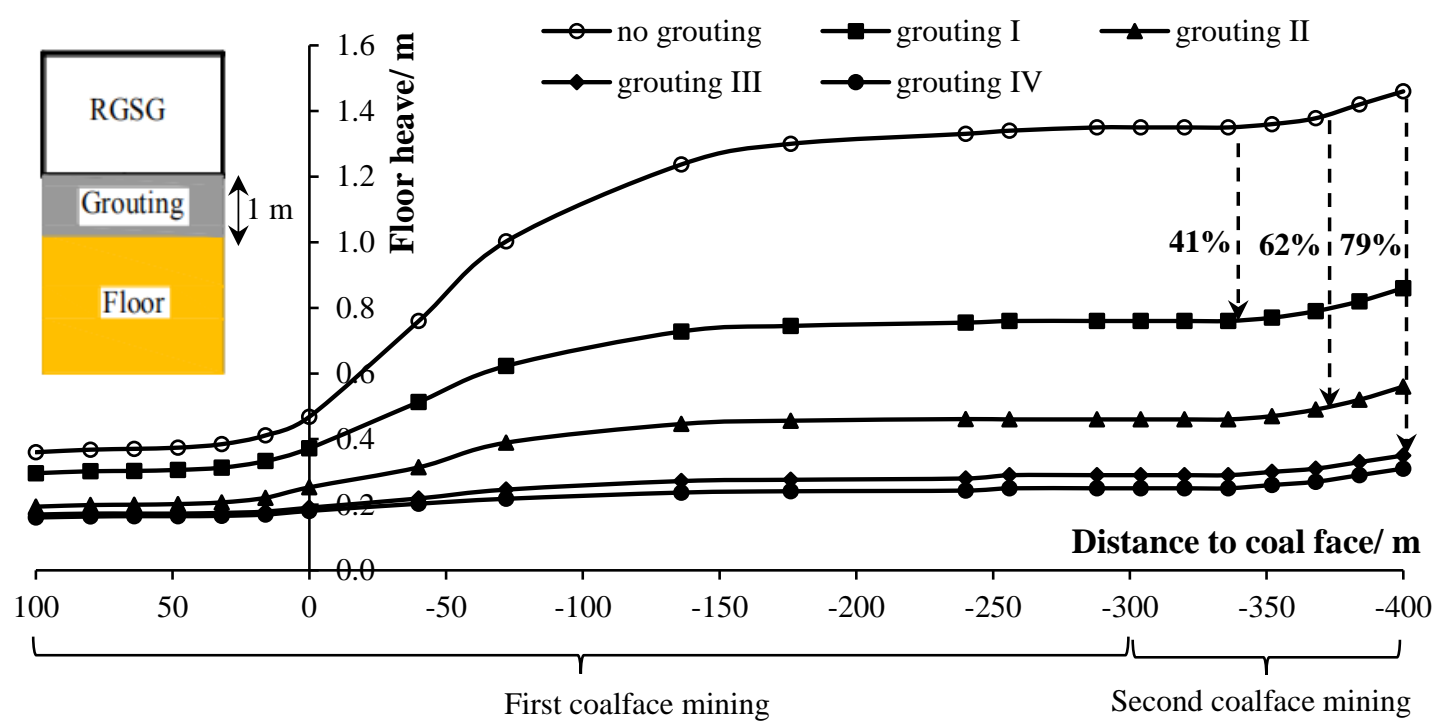

Figure 14. Floor heave of the RGSG after reinforcement with different grouting schemes.

\section{Conclusions}

In recent years, mining issues deep underground have been of great interest to researchers, in addition to practice engineers. In the present study, we focused on the stability maintenance of the deep RGSG in a modified Y-type longwall mining system. A numerical approach involving a strain softening constitute model was used to study the deformation distribution of the deep RGSG on the basis of geotechnical conditions of a deep underground coal mine $900 \mathrm{~m}$ in depth in the Anhui Province of China. The results demonstrated that floor heave was the main cause of roadway section shrinkage after experiencing excavation-induced stress disturbances three times. This was followed by investigating the mechanism of large floor heave and proposing corresponding grouting reinforcement. Finally, the effectiveness of this rock strengthening technique on deep RGSG floor heave was verified by introducing grouting induced mechanical improvements in the weak floor strata. The following conclusions were drawn:

(1) A reasonably good match was achieved between the field and numerical data, therefore, the proposed FLAC3D numerical simulation was verified as an effective approach to study the stability of the deep RGSG. In response to the disturbances from the roadway and coal panel I excavations, the RGSG surroundings performed significant deformations including $900 \mathrm{~mm}$ that belonged to two sidewalls and $1800 \mathrm{~mm}$ that belonged to the roof and floor, where floor heave accounted for $72 \%$ with $1300 \mathrm{~mm}$.

(2) Combined with floor heaving speed, we found that the variation of the ratio between the horizontal stress to the vertical stress in the floor strata was the root cause of the large floor heave of this deep RGSG. In particular, the influencing of this stress ratio on the floor heave could be divided into three stages: (1) slight influencing stage from $50 \mathrm{~m}$ to $16 \mathrm{~m}$ before the coal face; (2) intense influencing stage from $16 \mathrm{~m}$ before the coal face to $176 \mathrm{~m}$ behind the coal face; and (3) slight influencing stage from $176 \mathrm{~m}$ to $240 \mathrm{~m}$ behind the coal face. This can provide suggestions for the opportunity to select floor heaving control.

(3) Considering the soft rock mechanics of the weak rock mass surrounding the deep RGSG, grouting reinforcement was proposed to control the floor heave. Five grouting schemes were chosen after many numerical uniaxial compressive tests on grouted rock samples according to the improvements of residual strength. After grouting reinforcement, the plastic zone in the floor strata was reduced effectively, and the rock failure mechanisms partly changed to shear failure from tensile failure. Ideally, the floor heaves could be reduced by $41 \%, 62 \%$, and $79 \%$ when 
the floor strata of $1 \mathrm{~m}$ depth were reinforced with grouting schemes I, II, and III, respectively. This can provide suggestions for the grout selection during floor heaving control through grouting reinforcement technology.

Acknowledgments: This research was financially supported by the Xinjiang University Doctoral Science Foundation. Corporations and field measurements conducted by the engineers in the Zhuji coal mine are also much appreciated. The favors from the fellows in the rock mechanics lab of Kyushu University and Xinjiang University are also appreciated. We also thank Maxine Garcia from Liwen Bianji, Edanz Group China for editing the English text in a draft of this manuscript.

Author Contributions: All the authors contributed extensively to the work. Zhiyi Zhang proposed the key ideas and wrote the manuscript. Hideki Shimada contributed to the data analysis.

Conflicts of Interest: The authors declare no conflict of interest.

\section{References}

1. Yang, W.; Lin, B.Q.; Yan, Q.; Zhai, C. Stress redistribution of longwall mining stope and gas control of multi-layer coal seams. Int. J. Rock Mech. Min. Sci. 2014, 72, 8-15. [CrossRef]

2. Feng, G.; Hu, S.; Li, Z.; Jiang, H.; Zhang, Y.; Xu, G.; Wang, Z.; Kang, L. Distribution of methane enrichment zone in abandoned coal mine and methane drainage by surface vertical boreholes: A case study from China. J. Nat. Gas Sci. Eng. 2016, 34, 767-778. [CrossRef]

3. Zhang, N.; Zhang, N.; Esterle, J.; Kan, J.G.; Zhao, Y.M.; Xue, F. Optimization of gateroad layout under a remnant chain pillar in longwall undermining based on pressure bulb theory. Int. J. Min. Reclam. Environ. 2016, 30, 128-144. [CrossRef]

4. Goran, V.; Janez, M.; Bojan, L.; Željko, V. Rock burst dependency on the type of steel arch support in the Velenje mine. Mater. Tehnol. 2016, 51, 11-18.

5. Goran, V.; Maja, K.; Milivoj, V. Study of coal burst source locations in the Velenje colliery. Energies 2016, 9, 507. [CrossRef]

6. Yuan, L. Gas distribution of the mined-out side and extraction technology of first mined key seam relief-mining in gassy multi-seams of low permeability. J. China Coal Soc. 2008, 33, 1362-1367.

7. Li, H.M. Control design of roof rocks for gob-side entry. Chin. J. Rock Mech. Eng. 2000, 19, 651-654.

8. Hua, X.Z. Study on gob-side entry retaining technique with roadside packing in longwall top-coal caving technology. J. Coal Sci. Eng. 2004, 10, 9-12.

9. Zhu, C.Q.; Miao, X.X.; Liu, Z. Mechanical analysis on deformation of surrounding rock with road-in packing of gob-side entry retaining in fully-mechanized sub-level caving face. J. Coal Sci. Eng. 2008, 14, 24-28. [CrossRef]

10. Deng, Y.; Tang, J.; Zhu, X.; Fu, Y.; Dai, Z. Analysis and application in controlling surrounding rock of support reinforced roadway in gob-side entry with fully mechanized mining. Min. Sci. Technol. 2010, 20, 839-845. [CrossRef]

11. Ma, Z.; Gong, P.; Fan, J.; Geng, M.; Zhang, G. Coupling mechanism of roof and supporting wall in gob-side entry retaining in fully-mechanized mining with gangue backfilling. Min. Sci. Technol. 2011, 21, 829-833. [CrossRef]

12. Zhang, Y.Q.; Sun, L.L.; Zhang, W.Z.; Cao, L.D. The numerical simulation and supporting design of gob-side entry retaining in gradient medium thick coal seam. Appl. Mech. Mater. 2013, 368-370, 1812-1815. [CrossRef]

13. Deng, Y.; Wang, S. Feasibility analysis of gob-side entry retaining on a working face in a steep coal seam. Int. J. Min. Sci. Technol. 2014, 24, 499-503. [CrossRef]

14. Tan, Y.Y.; Yu, F.H.; Ning, J.G.; Zhao, T.B. Design and construction of entry retaining wall along a gob side under hard roof stratum. Int. J. Rock Mech. Min. Sci. 2015, 77, 115-121. [CrossRef]

15. Wang, H.; Zhang, D.; Liu, L.; Guo, W.; Fan, G.; Song, K.; Wang, X. Stabilization of gob-side entry with an artificial side for sustaining mining work. Sustainability 2016, 8, 627. [CrossRef]

16. Zhang, Z.; Shimada, H.; Sasaoka, T.; Hamanaka, A. Stability Control of Retained Goaf-Side Gateroad under Different Roof Conditions in Deep Underground Y Type Longwall Mining. Sustainability 2017, 9, 1671. [CrossRef]

17. Chen, Y.; Bai, J.; Yan, S.; Xu, Y.; Wang, X.; Ma, S. Control mechanism and technique of floor heave with reinforcing solid coal side and floor corner in goaf-side coal entry retaining. Int. J. Min. Sci. Technol. 2012, 22, 841-845. [CrossRef] 
18. Tang, S.B.; Tang, C.A. Numerical studies on tunnel floor heave in swelling ground under humid conditions. Int. J. Rock Mech. Min. Sci. 2012, 55, 139-150. [CrossRef]

19. Lin, D.; Wei, X.; Chunzhao, X.U.; Tang, B. Research on the type and deformation mechanism of floor heave of swelling soft rock roadway along goaf in deep mine. Min. Res. Dev. 2013, 33, 23-26.

20. Sun, X.M.; Chen, F.; He, M.C.; Gong, W.L.; Xu, H.C.; Lu, H. Physical modeling of floor heave for the deep-buried roadway excavated in ten degree inclined strata using infrared thermal imaging technology. Tunn. Undergr. Space Technol. 2017, 63, 228-243. [CrossRef]

21. Gong, P.; Ma, Z.; Ni, X.; Zhang, R. Floor heave mechanism of gob-side entry retaining with fully-mechanized backfilling mining. Energies 2017, 10, 2085. [CrossRef]

22. Mortazavi, A.; Hassani, F.P.; Shabani, M. A numerical investigation of rock pillar failure mechanism in underground openings. Comput. Geotech. 2009, 36, 691-697. [CrossRef]

23. Nakai, T. A generalized elastoplastic constitutive model for clay in a three-dimensional stresses. Soils Found. 1986, 26, 81-89. [CrossRef]

24. Zhang, Z.; Shimada, H.; Qian, D.; Sasaoka, T. Application of the retained gob-side gateroad in a deep underground coalmine. Int. J. Min. Reclam. Environ. 2016, 30, 371-389. [CrossRef]

25. Zhang, N. Theory and Practice of Surrounding Rock Control by Delayed Grouting of Roadway; China University of Mining and Technology Press: Xuzhou, China, 2004; pp. 14-38.

26. Huang, C.L.; Fan, J.C.; Yang, W.J. A study of applying microfine cement grout to sandy silt soil. Sino-Geotech 2007, 111, 71-82.

27. Liao, K.W.; Fan, J.C.; Huang, C.L. An artificial neural network for groutability prediction of permeation grouting with microfine cement grouts. Comput. Geotech. 2011, 38, 978-986. [CrossRef]

28. Lee, J.S.; Bang, C.S.; Mok, Y.J.; Joh, S.H. Numerical and experimental analysis of penetration grouting in jointed rock masses. Int. J. Rock Mech. Min. Sci. 2000, 37, 1027-1037. [CrossRef]

29. Utsuki, S. In-situ experimental studies on improvement of deformability of rock masses by grout treatment. Int. J. JCRM 2013, 9, 7-8.

30. Zolfaghari, A.; Sohrabi Bidar, A.; Maleki Javan, M.R.; Haftani, M.; Mehinrad, A. Evaluation of rock mass improvement due to cement grouting by Q-system at Bakhtiary dam site. Int. J. Rock Mech. Min. Sci. 2015, 74, 38-44. [CrossRef] 